\title{
PENDIDIKAN ISLAM DALAM MEMBANGUN KARAKTER BANGSA DI ERA MILENIAL
}

\author{
Syaiful Anwar ${ }^{1}$, Agus Salim ${ }^{2}$ \\ syaifulanwar@radenintan.ac.id \\ Universitas Islam Negeri Raden Intan Lampung ${ }^{1}$, SMA Negeri Bintuhan Bengkulu²:
}

\begin{abstract}
National character education aims to form a strong, competitive, moral, tolerant nation, mutual cooperation, patriotic spirit, dynamic development, knowledge and technology oriented all of which are inspired by faith and piety to the Almighty God as in aspiring to the Pancasila philosophy. Character education is an important issue in the world of education related to the phenomenon of moral decadence that occurs in the community as well as in an increasingly diverse and diverse government environment. Crime, injustice, corruption, violence against children, violation of human rights, are evidence that there has been a crisis of identity and characteristics of the Indonesian nation. The values of politeness, and religiosity that are upheld and become the culture of the Indonesian nation as long as it seems to be weak and feels foreign along with the entry of global cultural values (global culture of the era), so that it is rarely encountered in the midst of society. Islamic education is a strategic answer in realizing the formation of national character from the family (informal), institutional institutions (formal) and learning groups in the community (non-formal), which is the main capital in the formation of national character.
\end{abstract}

Keywords: Education, Islam, Character, Milenial

\begin{abstract}
Abstrak
Pendidikan karakter bangsa bertujuan membentuk bangsa yang tangguh, kompetitif, bermoral, bertoleran, bergotong royong, berjiwa patriotik, berkembang dinamis, berorientasi ilmu pengetahuan (knowledge) dan teknologi (technology) yang semuanya dijiwai oleh iman dan takwa kepada Tuhan yang Maha Esa seperti yang di cita-citakan palsafah Pancasila. Pendidikan karakter menjadi isu penting dalam dunia pendidikan berkaitan dengan fenomena dekadensi moral yang terjadi ditengah masyarakat maupun di lingkungan pemerintah yang semakin meningkat dan beragam. Kriminalitas, ketidak adilan, korupsi, kekerasan pada anak, pelangggaran HAM, menjadi bukti bahwa telah terjadi krisis jati diri dan karakteristik pada bangsa Indonesia. Nilai-nilai kesantunan, dan relegiusitas yang dijunjung tinggi dan menjadi budaya bangsa Indonesia selama ini seakan-akan menjadi lemah dan terasa asing seiring dengan masuknya nilai-nilai budaya global (global culture of the millenials era), sehingga jarang ditemui ditengah-tengah masyarakat. Pendidikan Islam menjadi sebuah jawaban strategis dalam mewujudkan pembentukan karakter bangsa mulai dari keluarga (informal), lembaga institusi (formal) maupun kelompok-kelompok belajar di masyarakat (nonformal), yang merupakan modal utama dalam pembentukan karakter bangsa.
\end{abstract}

Kata Kunci: Pendidikan, Islam, Karakter, Milenial 


\section{PENDAHULUAN}

Arus perkembangan globalisasi telah melahirkan generasi gadget, istilah digunakan untuk menandai munculnya generasi millennial. Gadget sebenarnya lebih tepat diartikan dengan peralatan teknologi, sehingga kehidupan masyarakat selalu bersinggungan dengan unsur teknologi informasi. Jadi seolah-olah berbagai peralatan high-technology tersebut telah menjadi bagian yang tak terpisahkan dari kehidupan mereka (Naisbitt, Naisbitt, \& Philips, 2002; Wahana, 2015; Zuhal, 2000).

Berdasarkan hasil penelitian terdahulu, telah dilakukan beberapa penelitian tentang pendidikan islam (Almasri, 2016; Kasim \& Husain, 2008; Sawaluddin, 2018) untuk membangun karakter (Anwar, 2016; Hasyim, 2015; Juanda, 2018; Martini, 2018; Munif, 2018; Rachmah, 2013; Saputra, 2012; Shobahiya \& Suseno, 2013; Situmorang, 2013; Wahono, 2018; Wardani, Widodo, \& Priyani, 2009; Wibowo, 2014) di era milenial (Ambarwati \& Raharjo, 2018; Habibi, 2018; Juwita, 2018; Mucharomah, 2017; Putri, 2017; Wahana, 2015) serta hubungan antara pendidikan islam dalam membentuk karakter (Basri, 2017; Nata, 2018), pendidikan islam dalam era milenial (Hidayat, 2018; Rafid, 2018) dan pendidikan karakter di era milenial (Akhsania, 2018; Lalo, 2018; Muslich, 2018). Namun, belum terdapat penelitian sebelumnya yang mengungkapkan tentang peranan pendidikan Islam untuk memberikan edukasi dan filter terhadap perkembangan teknologi.

Berdasarkan beberapa penelitian terdahulu, Penelitian ini mencoba mendiskripsikan dan menganalisis persefektif pendidikan dalam membangun karakter bangsa dalam arus globalisasi/era milenial. Pertanyaan mendasar yang dikemukakan dalam konteks ini adalah "bagaimanakah peran pendidikan dalam membentuk karakter nasional yang dapat dijadikan soft power sebagai modal untuk menghadapi persaingan di era globalisasi?"

\section{HASIL KAJIAN DAN PEMBAHASAN}

Pendidikan Islam sebagai sebuah sistem Pendidikan, tidak dipungkiri memiliki kontribusi yang cukup mapan untuk menyokong pembentukan karakter bangsa dengan berbagai strategi dan metode yang cukup mengesankan dan menyakinkan. Seperti terlihat pada sistem pengajaran pada pendidikan Islam yang diarahkan bukan hanya pencapaian peningkatan kecerdasan (akal) semata bagi peserta didik namun yang lebih 
esensial dalam pendidikan Islam justru diharapkan melahirkan Insan yang paripurna (memiliki keimanan dan akhlak mulia). Demikian juga dalam proses pencapaian tersebut pendidikan Islam tidak hanya menjadi beban bagi pendidik (guru) justru tanggung jawab pertama dan utama orang tua di rumah tangga dalam membentuk keperibadian anaknya mulai dari kandungan, lahir bahkan sampai aqil baligh. Peranan orang tua dapat memberikan rasa nyaman, aman dan keamanan dalam menanamkan nilai-nilai moral dan agama sejak dini pada anak-anak mereka (Basri, 2017).

Dilihat dari sudut pengertian, ternyata karakter dan akhlak tidak memiliki perbedaan yang signifikan. Keduanya didefinisikan sebagai suatu tindakan yang terjadi tanpa adalagi pemikiran, karena sudah tertanam dalam pikiran, dan dengan kata lain, keduanya dapat disebut dengan kebiasaan. Pengertian karakter menurut Pusat Bahasa Depdiknas adalah: bawaan, hati, jiwa, keperibadian, budipekerti, perilaku, personalitas, sifat, tabiat, temperamen, watak. Adapaun berkarakter adalah berkepribadian, berperilaku, bersifat, bertabi'at, dan berwatak.

Menurut Fakhry Gaffar, pendidikan karakter adalah sebuah proses transformasi nilai-nilai kehidupan untuk ditumbuhkembangkan dalam kepribadian seseorang sehingga menjadi satu dalam perilaku kehidupan orang itu. Dalam definisi tersebut ada tiga ide pikiran penting, yaitu: (1) proses transformasi nilai-nilai, (2) ditumbuhkembangkan dalam kepribadian, (3) menjadi satu dalam perilaku (Hasyim, 2015). Menurut Majid, pendidikan karakter adalah sebuah upaya untuk membimbing perilaku manusia menuju standar-standar baku (Majid \& Andayani, 2012). Fokus pendidikan karakter adalah pada tujuan-tujuan etika, tetapi prakteknya meliputi penguatan kecakapan-kecakapan yang penting yang mencakup perkembangan sosial siswa.

Nilai-nilai pendidikan karakter yang dikembangkan di Indonesia yaitu bersumber dari agama, Pancasila, budaya, dan tujuan pendidikan nasional, yaitu: 1) Religius, 2) Jujur, 3) Toleransi, 4) Disiplin, 5) Kerja Keras, 6) Kreativ, 7) Mandiri, 8) Demokratis, 9) Rasa Ingin Tahu, 10) Semangat Kebangsaan, 11) Cinta Tanah Air, 12) Menghargai Prestasi, 13) Bersahabat/Komunikatif, 14) Cinta Damai, 15) Gemar Membaca, 16) Peduli Lingkungan, 17) Peduli Social, 18) Tanggung Jawab (Dalimunthe, 2015; Hamid \& Sudira, 2013). Nilai-nilai karakter tersebut dapat di rujuk dalam mengembangkan karakter bangsa dalam praktek pendidikan (Informal, formal 
dan non formal), pembiasaan yang diberikan contoh secara kontinu karena karakter tidak terbentuk secara instan, tapi harus dilatih secara serius dan proporsional agar mencapai bentuk dan kekuatan yang ideal.

Karakter Bangsa adalah salah satu dari sembilan unsur kekuatan nasional tak kasat mata (intangible) suatu bangsa. Sebagai salah satu kekuatan nasional, karakter nasional harus dipelihara dan senantiasa direvitalisasi agar selalu bisa menjadi inspirasi, pengobar semangat dan mampu berfungsi sebagai human capital sebuah bangsa karena karakter nasional menentukan ketahanan nasional bangsa yang bersangkutan.

Berkaitan dengan konteks karakter sebuah bangsa, maka yang menjadi tolok ukur penting dalam menilai keberhasilannya adalah sejauh mana keberhasilan bangsa tersebut memajukan pendidikan nasional, yang bertumpu pada tiga komponen, yaitu kognitif, afektif dan psikomotorik. Dengan kata lain, pendidikan diartikan sebagai pembiasaan, pembelajaran, peneladanan, bukan sekedar penyekolahan (schooling). Sebagai sebuah konvensi, peradaban manapun meniscayakan pembangunan karakter nasional merupakan bagian tak terpisahkan dari tujuan pembangunan nasional secara umum dan pembangunan bidang pendidikan pada khususnya.

Saat ini Indonesia sedang dihadapkan pada permasalahan melemahnya karakter bangsa. Hal ini ditunjukkan dengan berbagai persoalan bangsa yang gejalanya mulai nampak perlahan-lahan semenjak beberapa dekade terakhir. Jika tidak segera diatasi persoalan ini dapat mengancam eksistensi dan keamanan bangsa Indonesia. Beberapa permasalahan akut yang sedang dihadapi bangsa Indonesia antara lain, lemahnya kepemimpinan nasional, lemahnya semangat juang (fighting spirit) generasi muda, tingginya tingkat korupsi dan krisis identitas. Dampak yang ditimbulkan dari permasalahan ini bermacam-macam, misalnya ancaman disintegrasi, lemahnya daya saing Indonesia di tingkat internasional, terpuruknya image Indonesia di mata dunia. Berbagai persoalan yang menyelimuti bangsa ini menimbulkan pertanyaan: bagaimanakah pendidikan di Indonesia diselenggrakan sehingga menghasilkan kualitas sumber daya manusia (SDM) yang secara umum belum siap bersaing di era liberalisasi? Peran pendidikan di Indonesia hanya parsial dengan penekanan pada pengembangan aspek kognitif, sehingga hasil pendidikan tidak memiliki korelasi dengan sikap maupun perilaku peserta didik. Pendidikan dianggap tidak memberikan kontribusi signifikan pada pembentukan karakter bangsa sesuai dengan core values. 
Pertanyaan mendasar yang dikemukakan dalam konteks ini adalah: bagaimanakah peran pendidikan dalam membentuk karakter nasional yang dapat dijadikan soft power sebagai modal untuk menghadapi persaingan di era globalisasi? Argumen yang dicoba dikemukanan di sini adalah, pendidikan merupakan elemen dasar yang harus dibangun, diperkuat dan diutamakan jika bangsa Indonesia ingin menuju ke arah tersebut. Pencapaian survival of the fittest dalam era globalisasi dapat dicapai dengan menampil-kan soft power sebagai modalitas.

Berdasarkan data dan fakta serta analisis para pakar pendidikan, paling tidak terdapat empat faktor utama yang memerlukan perhatian dalam konteks pendidikan nasional, yaitu: faktor kurikulum, faktor dana, faktor kesiapan tenaga pendidik dan faktor lingkungan sekitar dan suasana yang kondusif bagi penyelenggaraan pendidikan. Keempat faktor initerkait satu sama lain untuk dapat menghasilkan SDM dengan karakter nasional yang mampu bersaing di era global. Pembentukan dan pendidikan karakter tersebut, tidak akan berhasil jika antar lingkungan pendidikan tidak ada kesinambungan dan keharmonisan

Dengan demikian, rumah tangga dan keluarga sebagai lingkungan pembentukan pendidikan karakter pertama dan utama harus lebih diberdayakan. Hurlock juga mendefinisikan bahwa keluarga merupakan "Training Centre" bagi penanaman nilainilai karakter dan pengembangan fitrah atau jiwa beragama anak, bersamaan dengan perkembangan kepribadiaannya (Hurlock, 1986). Keluarga sebagai unit terkecil dari masyarakat hendaklah kembali menjadi school of love, sekolah untuk kasih sayang atau tempat belajar yang penuh cinta sejati dan kasih sayang (keluarga yang sakinah, mawaddah, danwarrahmah). Sedangkan pendidikan karakter melalui sekolah, tidak semata-mata pembelajaran pengetahuan semata, tatapi lebih dari itu, yaitu penanaman moral, nilai-nilai etika, estetika, budi pekerti yang luhur dan lain sebagainya. Pemberian penghargaan (prizing) kepada yang berprestasi, dan hukuman kepada yang melanggar, menumbuhsuburkan (cherising) nilai-nilai yang baik dan sebaliknya mengecam dan mencegah (discowaging) berlakunya nilai-nilai yang buruk (Mini, 2017; Yuliana, 2012).

Pembangungan karakter menempatkan pendidikan sebagai salah satu strategi dasar dari pembangunan karakter bangsa yang dalam pelaksanaanya harus dilakukan secara koheren dengan beberapa strategi yang mencakup sosialisasi atau penyadaran, pemberdayaan, pembudayaan dan kerjasama seluruh komponen bangsa. Pembangunan 
karakter dilakukan dengan pendekatan sistematik dan integratif dengan melibatkan keluarga, satuan pendidikan, pemerintah, masyarakat sipil, anggota legislatif, media massa, dunia usaha dan industry.

Dalam melaksanakan dan mengawal pembentukan karakter bangsa diperlukan komitmen yang serius sehingga penanaman nilai-nilai kebaikan kepada warga sekolah dapat menjadikan peserta didik menjadi insan paripurna yang tentu saja melibatkan isi kurikulum, proses pembelajaran dan penilaian, kualitas hubungan warga sekolah, pengelolaan pembelajaran, pengelolaan berbagai kegiatan peserta didik, pemberdayaan sarana dan prasarana serta etos kerja seluruh warga sekolah yang berdasarkan kepada Pancasila, UUD 1945, NKRI dan rasa cinta dan bela terhadap negara dan tanah air.

Keberhasilan suatu bangsa dalam mencapai tujuannya sangat ditentukan oleh kualitas sumber daya manusianya. Bahkan dapat dikatakan bahwa "bangsa yang besar dapat dilihat dari kualitas/karakter bangsa (manusia) itu sendiri”. Membangun berarti bersifat memperbaiki, membina, mendirikan, dan mengadakan sesuatu. Karakter adalah tabiat, watak, sifat-sifat kejiwaan, akhlak atau budi pekerti yang membedakan seseorang dari yang lainnya. Jadi membangun karakter adalah suatu proses atau usaha yang dilakukan untuk membina, memperbaiki dan atau membentuk tabiat, watak, sifat kejiwaan, akhlak, insan manusia sehingga menunjukkan perangai dan tingkah laku yang baik berlandaskan nilai-nilai Pancasila (Suhady \& Sinaga, 2006).

Nilai-nilai Pancasila sebagai falsafah hidup bangsa perlu diimplementasikan untuk membangkitkan karakter bangsa yang semakin menurun. Pancasila merupakan refleksi kritis dan rasional sebagai dasar negara dan kenyataan budaya bangsa, dengan tujuan untuk mendapatkan pokok-pokok pengertiannya secara mendasar dan menyeluruh. Pancasila sebagai ideologi baik dalam pengertian ideologi negara atau ideologi bangsa masih dipertahankan. Namun, seiring kesalahan tafsir bahwa Pancasila dipergunakan untuk memperkuat otoritarianisme negara. Salah satu ciri kekuasaan yang otoriter di manapun adalah selalu menganggap ideologi sebagai maha penting yang berhubungan erat dengan stabilitas atau kohesisosial. Tetapi asumsi bahwa usaha menyeragamkan ideologi penting demi menciptakan stabilitas dan memperkuat kohesi masyarakat adalah menyesatkan (Rachmah, 2013; Wahyudi, 2004).

Bagaimanapun sejarah telah membuktikan bahwa nilai materil Pancasila merupakan sumber kekuatan bagiperjuangan bangsa Indonesia. Nilai-nilai Pancasila 
merupakan pengikat sekaligus pendorong dalam usaha menegakkan dan memperjuangkan kemerdekaan sehingga menjadi bukti bahwa Pancasila sesuai dengan kepribadian dan keinginan bangsa Indonesia. Pancasila merupakan sublimasi nilai-nilai budaya yang mernyatukan masyarakat Indonesia yang beragam suku, ras, bahasa, agama, pulau, menjadi bangsa yang satu. Nilai-nilai yang terkandung atau sarjana yang piawai dalam menjawab soal ujian, berotak cerdas, tetapi mental dan moralnya lemah. Penyebabnya adalah banyak pakar bidang moral dan agama yang sehari-hari mengajar tentang kebaikan tetapi perilakunya tidak sejalan dengan ilmu yang diajarkan (Rachmah, 2013).

Sejak kecil, anak-anak diajarkan menghafal tentang bagusnya sikap jujur, berani, kerja keras, kebersihan dan jahatnya kecurangan. Tetapi nilai-nilai kebaikan itu diajarkan dan diujikan sebatas pengetahuan di atas kertas dan dihafal sebagai bahan yang wajib dipelajari saja. Pendidikan karakter bukanlah sebuah proses menghafal materi saol ujian saja tetapi justu memerlukan pembiasaan. Pembiasaan untuk berbuat baik, berlaku jujur, ksatria, malu berbuat curang, malu bersikap malas, malu membiarkan lingkungan kotor. Karakter tidak terbentuk secara instan, tapi harus dilatih secara serius dan proporsional agar mencapai bentuk dan kekuatan yang ideal (Husaini, 2010; Shobahiya \& Suseno, 2013).

Meskipun demikian satuan pendidikan dapat menentukan prioritas pengembangan-nya untuk melanjutkan nilai-nilai pra kondisi yang telah dikembangkan. Implementasi nilai-nilai karakter yang akan dikembangkan dapat dimulai dari nilai-nilai yang esensial, sederhana dan mudah dilaksanakan, seperti: bersih, rapi, nyaman, disiplin, sopan dan santun (Kemdiknas, 2011:8). Oleh karena itu pendidikan karakter bertujuan mengembangkan nilai-nilai yang membentuk karakter bangsa yaitu Pancasila yang meliputi : a) mengembangkan potensi peserta didik agar menjadi manusia berhati baik, berpikiran baik dan berprilaku baik, b) Membangun bangsa yang berkarakter Pancasila, c) mengembangkan potensi warga negara agar memiliki sikap percaya diri, bangga pada bangsa dan negaranya serta mencintai umat manusia.

Selama ini nilai-nilai dan prinsip-prinsip UUD1945 dan Pancasila telah diwariskan dan telah menjadi kesepakatan seluruh rakyat seperti Proklamasi Kemerdekaan, lima sila dalam Pancasila, dan Negara Kesatuan Republik Indonesia yang tercermin dalam pembukaan UUD 1945. Sementara prinsip-prinsip penjelmaan 
Pancasila yang tercantum dalam UUD 1945 mengenai negara kesatuan yang berbentuk republik, menjunjung tinggi hak asasi manusia, sistem Bhineka Tunggal Ika, kesamaan kedudukan dalam hukum dan pemerintah, sistem ekonomi sebagai usaha bersama atas dasar kekeluargaan, sistem pembelaan negara berdasarkan hak dan kewajiban semua warga negara, pemerintahan presidentil dan pengawasan oleh DPR (Suhady \& Sinaga, 2006).

Dengan demikian, melihat nilai-nilai dan prinsip-prinsip UUD 1945 tersebut, maka pendidikan karakter yang dikembangkan memang mengarah kepada nilai dan prinsip tersebut yang intinya untuk membentuk bangsa yang tangguh, kompetitif, berakhlak mulia, bermoral, bertoleran, bergotong royong, berjiwa patriotik, berkembang dinamis, berorientasi ilmu pengetahuan dan teknologi yang semuanya dijiwai oleh iman dan takwa kepada Tuhan yang Maha Esa.

Kecanggihan teknologi akhir ini hampir merubah tatanan pola pikir bagi masyarakat, dari anak usia dini, remaja, orang tua, guru/dosen, juga mulai dari kalangan menengah sampai dengan kalangan atas. Maraknya budaya global (global culture) dan gaya hidup (lifestyle) menjadi dampak dari arus globalisasi yang sudah tidak bisa dibendung lagi. Kecangggihan high-technology telah menjadi bagian yang tak terpisahkan dari kehidupan masyarakat, seolah-olah berbagai alat high-technology menjadi bagian penting dalam kehidupannya (Basri, 2017; Naisbitt et al., 2002; Wahana, 2015; Zuhal, 2000)

Berbagai penelitian tentang dampak dan pemanfaatan internet (high-technology) menunjukkan bahwa high-technology seperti internet dapat menjadi sumber utama untuk belajar, tentang apa yang sedang terjadi di dunia seperti untuk hiburan, bergembira, relaksasi, untuk melupakan masalah, menghilangkan kesepian, untuk mengisi waktu sebagai kebiasaan dan melakukan sesuatu dengan teman atau keluarga (Heru Dwi Wahana, 2015).

Kecanggihan dalam mengakses informasi melalui teknologi tersebut membutuhkan respon yang proaktif untuk memfilter terjadinya penurunan nilai-nilai karakter masyarakat. Jika hal ini tidak dilakukan akan menimbulkan dampak buruk bagi masyarakat, seperti terjadinya criminal social seperti pelecehan seksual, anak melawan terhadap orang tua, siswa menganiaya guru. Menurut Daradjat semakin merosotnya moral para pelajar merupakan salah satu akibat dari pesatnya perkembangan teknologi 
yang tidak diimbangi dengan peningkatan kualitas budi pekerti pelajar, padahal perkembangan teknologi memang sangat dibutuhkan bangsa ini untuk dapat terus bersaing di era globalisasi (Darajat, 1982). Kemerosotan moral banyak dipengaruhi oleh kondisi sosial-budaya dalam masyarakat sekitarnya. Lingkungan sosial yang buruk adalah bentuk dari kurangnya pranata sosial dalam mengendalikan perubahan sosial yang negatif.

Kemerosotan karakter yang dihadapi sekolah dan masyarakat seiring masuknya nilai budaya global, seperti hadirnya nilai-nilai budaya generasi millenial (generasi yang menjadikan teknologi informasi sebagai gaya hidup atau lifestyle) yang dipicu oleh perkembangan teknologi informasi, tentu akan berpengaruh terhadap aspek pendidikan sekolah maupun kehidupan individu dalam keluarga, baik positif maupun negatif. Kebiasaan gaya hidup tersebut ditandai dengan tingginya kebutuhan terhadap teknologi yang semakin canggih, kebutuhan terhadap gadget yang seakan tidak dapat terpisahkan dengan kebiasaan sehari-hari. Disinilah peranan pendidikan Islam sebagai sebuah sistem pendidikan, tidak dipungkiri memiliki konstribusi yang cukup mapan untuk pembentukan karakter bangsa dengan berbagai strategi dan metode yang cukup dalam.

Konsep pendidikan karakter sebenarnya telah ada sejak zaman rasulullah SAW. Hal ini terbukti dari perintah Allah bahwa tugas pertama dan utama Rasulullah adalah sebagai penyempurna akhlak bagi umatnya. Pembahasan substansi makna dari karakter sama dengan konsep akhlak dalam Islam, keduanya membahas tentang perbuatan prilaku manusia. Al-Ghazali menjelaskan jika akhlak adalah suatu sikap yang mengakar dalam jiwa yang darinya lahir berbagai perbuatan dengan mudah dan gampang tanpa perlu adanya pemikiran dan pertimbangan. Suwito menyebutkan bahwa akhlak (karakter) sering disebut juga ilmu tingkah laku atau perangai, karena dengan ilmu tersebut akan diperoleh pengetahuan tentang keutamaan-keutamaan jiwa; bagaimana cara memperolehnya dan bagaiman membersihkan jiwa yang telah kotor (Ainiyah, 2013; Suwito, 2004).

Karakter dalam Islam adalah sasaran utama dalam pendidikan Islam. Hal ini dapat dilihat dari beberapa hadits nabi yang menjelaskan tentang keutamaan pendidikan akhlak salah satunya hadits berikut ini: “ajarilah anak-anakmu kebaikan, dan didiklah mereka". Konsep pendidikan didalam Islam memandang bahwa manusia dilahirkan dengan membawa potensi lahiriah yaitu:1) potensi berbuat baik terhadap alam, 2) 
potensi berbuat kerusakan terhadap alam, 3) potensi ketuhanan yang memiliki fungsifungsi nonfisik. Ketiga potensi tersebut kemudian diserahkan kembali perkembangannya kepada manusia. Hal ini yang kemudian memunculkan konsep pendekatan yang menyeluruh dalam pendidikan Islam yaitu meliputi unsur pengetahuan, akhlak dan akidah. Secara luas Ibnu Faris menjelaskan bahwa konsep pendidikan Islam adalah membimbing seseorang dengan memperhatikan segala potensi paedagogik yang dimilikinya, melalui tahapan-tahapan yang sesuai, untuk didik jiwanya, akhlaknya, akalnya, fisiknya, agamanya, rasa sosial politiknya, ekonominya, keindahannya, dan semangat jihadnya (Suwito, 2004).

Hal ini memunculkan konsep pendidikan Islam yang komprehensif, dimana tuntutan hakiki dan terintegrasi dengan nilai-nilai budaya yang baik, karena kehidupan manusia yang sebenarnya adalah keseimbangan hubungan antara manusia dengan tuhannya, hubungan manusia dengan sesamanya serta hubungan manusia dengan lingkungan disekitarnya. Karakter selalu menjadi sasaran utama dari proses pendidikan dalam Islam, karena karakter dianggap sebagai dasar bagi keseimbangan kehidupan manusia yang menjadi penentu keberhasilan bagi potensi paedagogis yang lain sehingga terbentuknya karakter sebagai sasaran dari pendidikan Islam tersebut. Oleh karena itu Islam mengutamakan proses pendidikan sebagai agen pembentukan akhlak pada anak.

Uraian diatas menggambarkan bahwa pendidikan merupakan agen perubahan yang signifikan dalam pembentukan karakter bangsa, dan pendidikan Islam menjadi bagian yang penting dalam proses tersebut, tetapi yang menjadi persoalan selama ini adalah pendidikan Islam disekolah hanya diajarkan sebagai sebuah pengetahuan tanpa adanya pengaplikasian dalam kehidupan sehari-hari. Sehingga fungsi pendidikan Islam sebagai salah satu pembentukan karakter dan akhlak mulia bagi siswa tidak tercapai dengan baik.

Disinilah dibutuhkan kreatifitas guru dalam menyampaikan pendidikan Islam seharusnya tidak hanya diajarkan didalam kelas saja, tetapi bagaimana guru dapat memotivasi dan memfasilitasi pembelajaran agama diluar kelas melalui kegiatankegiatan yang bersifat keagamaan dan menciptakan lingkungan pendidikan yang religius dan tidak terbatas oleh jam pelajaran saja.

Pendidikan karakter atau akhlak tidak dapat diajarkan hanya dalam bentuk pengetahuan saja,tetapi perlu adanya pembiasaan dalam prilakunya sehari-hari. Setelah 
menjadi teladan yang baik, guru harus mendorong siswa untuk selalu berprilaku baik dalam kehidupan sehari-hari. Oleh karena itu selain menilai, guru juga menjadi pengawas terhadap prilaku siswa sehari-hari di sekolah, dan disinilah pentingnya dukungan dari semua pihak. Karena didalam metode pembiasaan siswa dilatih untuk mampu membiasakan diri berprilaku baik dimana saja, kapan saja dan dengan siapa saja.

Pemberian pengetahuan tentang aqidah yang benar menjadi dasar yang paling utama dalam penanaman akhlak pada anak. Disinilah pentingnya pembelajaran pendidikan Islam di sekolah, karena pendidikan agama merupakan pondasi bagi pembelajaaran ilmu pengetahuan lain, yang akan menghantarkan terbentuknya anak yang berkepribadian, agamis dan berpengetahuan tinggi. Maka tepat jika dikatakan bahwa penerapan Pendidikan Islam disekolah adalah sebagai pilar pendidikan karakter yang utama. Pendidikan agama mengajarkan pentingnya penanaman akhlak yang dimulai dari kesadaran beragama pada anak.

\section{SIMPULAN DAN SARAN}

Pendidikan karakter bangsa merupakan bagian integral yang tak terpisahkan dari pendidikan nasional secara utuh. Pendidikan karakter bangsa harus dikembangkan secara komprehensif sebagai proses pembudayaan. Pendidikan karakter bangsa merupakan tanggung jawab bersama antara pemerintah, masyarakat, sekolah dan orangtua. Oleh karena itu pelaksanaan budaya dan karakter bangsa harus melibatkan keempat unsur tersebut. Dalam upaya merevitalisasi pendidikan karakter bangsa diperlukan gerakan nasional guna menggugah semangat kebersamaan dalam pelaksanaan di lapangan. Pendidikan Islam sebagai sebuah sistem Pendidikan, memiliki pengaruh yang cukup besar untuk menyokong pembentukan karakter bangsa dengan berbagai strategi, pendekatan dan metode yang cukup dalam dan mendasar. Agar pendidikan karakter bangsa yang otentik bisa berhasil dengan baik, an-Nahlawi telah mencoba merumuskan berbagai strategi penanaman pengetahuan dan nilai. Di antara strategi tersebut adalah: (a) mendidik melalui dialog Qur'ani dan Nabawi, (b) mendidik melalui kisah Qur'ani dan Nabawi, (c) mendidik melalui perumapamaan, (d) mendidik melalui keteladanan, (e) mendidik melalui praktek dan perbuatan, (f) mendidik melalui ibrah dan Mau'idzah, (g) pendidikan melalui targhib dan tarhib. 


\section{DAFTAR PUSTAKA}

A., D. K. (2009). Pendidikan Karakter di Zaman Keblinger: Mengembangkan Visi Guru Sebagai Pelaku Perubahan dan Pendidikan Karakter. Jakarta: Grasindo.

Ainiyah, N. (2013). Pembentukan Karakter melalui Pendidikan Agama Islam. Jurnal Al-Jabar: Jurnal Pendidikan Matematika, 13(1), 25-38.

Akhsania, K. N. (2018). Pendidikan Karakter Prososial di Era Milenial dengan Pendekatan Konseling Realitas. In Prosiding SNBK (Seminar Nasional Bimbingan dan Konseling) (Vol. 2, Pp. 228-233).

Almasri, M. N. (2016). Manajemen Sumber Daya Manusia: Imlementasi dalam Pendidikan Islam. Kutubkhanah: Jurnal Penelitian Sosial Keagamaan, 19(2), $133-151$.

Ambarwati, A., \& Raharjo, S. T. (2018). Prinsip Kepemimpinan Character of a Leader pada Era Generasi Milenial. Philanthropy Journal Of Psychology, 2(2), 114 127.

Anwar, S. (2016). Peran Pendidikan Agama Islam dalam Membentuk Karakter Bangsa. Al-Tadzkiyyah: Jurnal Pendidikan Islam, 7(2), 157-169.

Basri, S. (2017). Konsep Pendidikan Islam dalam Membentuk Karakter Bangsa di Era Globalisasi. Jurnal An-Nur, 5(2), 120-131.

Dalimunthe, R. A. A. (2015). Strategi dan Implementasi Pelaksanaan Pendidikan Karakter Di SMP N 9 Yogyakarta. Jurnal Pendidikan Karakter, V(1), 102-111.

Darajat, Z. (1982). Pendidikan Agama dalam Pembinaan Mental. Jakarta: Bulan Bintang.

Habibi, M. (2018). Optimalisasi Dakwah melalui Media Sosial di Era Milenial. AlHikmah: Jurnal Dakwah, 12(1), 101-116.

Hamid, A., \& Sudira, P. (2013). Penanaman Nilai-Nilai Karakter Siswa SMK Salafiyah Program Keahlian Teknik Komputer dan Jaringan (TKJ) Kajen, Margoyoso, Pati, Jawa Tengah. Jurnal Pendidikan Vokasi, 2(3), 1-15.

Hasyim, M. (2015). Konsep Pendidikan Karakter Perspektif Umar Baradja dan Relevansinya dengan Pendidikan Nasional. Cendekia: Jurnal Studi Keislaman, l(2), 151-169.

Hidayat, A. (2018). Metode Pendidikan Islam untuk Generasi Millennial. Fenomena: Jurnal Penelitian, 10(1), 55-76. 
Hurlock, E. B. (1986). Personality Development. New Delhi: Mcgrill Hill.

Husaini, A. (2010). Pendidikan Islam Membangun Manusaia Berkarakter dan Beradab. Bogor: Insists.

Iswan, \& Herwina. (2018). Penguatan Pendidikan Karakter Perspektif Islam dalam Era Millenial Ir. 4.0. In Seminar Nasional Pendidikan Era Revolusi "Membangun Sinergitas dalam Penguatan Pendidikan Karakter pada Era IR 4.0” (pp. 21-42). Jakarta: Universitas Muhammadiyah Jakarta.

Juanda. (2018). Revitalisasi Nilai dalam Dongeng sebagai Wahana Pembentukan Karakter Anak Usia Dini. Jurnal Pustaka Budaya, 5(2), 11-18.

Juwita, D. R. (2018). Pendidikan Akhlak Anak Usia Dini di Era Millennial. At-Tajdid: Jurnal Ilmu Tarbiyah, 7(2), 282-314.

Kasim, T. S. A. T., \& Husain, F. B. C. (2008). Pendekatan Individu dalam Pengajaran Pendidikan Islam sebagai Wahana Melahirkan Modal Insan Bertamadun. Jurnal Usuluddin, 27, 141-156.

Lalo, K. (2018). Menciptakan Generasi Milenial Berkarakter dengan Pendidikan Karakter Guna Menyongsong Era Globalisasi. Jurnal Ilmu Kepolisian, 12(2), $68-75$.

Majid, A., \& Andayani, D. (2012). Pendidikan Karakter Perspektif Islam. Bandung: Remaja Rosdakarya.

Martini, E. (2018). Membangun Karakter Generasi Muda melalui Model Pembelajaran Berbasis Kecakapan Abad 21. Jurnal Pancasila dan Kewarganegaraan, 3(2), $21-27$.

Mini, R. (2017). Peningkatan Mutu Sumber Daya Manusia melalui Pendidikan Karakter dan Arritude. Nur El-Islam: Jurnal Pendidikan dan Sosial Keagamaan, 4(2), 79-96.

Mucharomah, M. (2017). Guru di Era Milenia dalam Bingkai Rahmatan Lil Alamin. Edukasia Islamika, 2(2), 201-221.

Munif, M. (2018). Pendidikan Karakter dalam Bahan Ajar Bahasa Arab Kelas 3 Madrasah Ibtida'iyah Kurikukulum 2013. Islamic Review: Jurnal Riset dan Kajian Keislaman, Vii(2), 137-157.

Muslich, A. (2018). Nilai-Nilai Filosofis Masyarakat Jawa Dalam Konteks Pendidikan Karakter Di Era Milenial. Al-Asasiyya: Journal Basic Of Education, 2(2), 65- 
78.

Naisbitt, J., Naisbitt, N., \& Philips, D. (2002). High Tech High Touch: Pencarian Makna di Tengah Perkembangan Teknologi. Jakarta: Pustaka Mizan.

Nata, A. (2018). Pendidikan Islam di Era Milenial. Conciencia: Jurnal Pendidikan Islam, 18(1), 10-28.

Putri, N. P. (2017). Eksistensi Bahasa Indonesia pada Generasi Millennial. Widyabastra, 5(1), 45-49.

Rachmah, H. (2013). Nilai-Nilai dalam Pendidikan Karakter Bangsa yang Berdasarkan Pancasila dan UUD 1945. E-Journal Widya non-Eksakta, 1(1), 7-14.

Rafid, R. (2018). Konsep Kepribadian Muslim Muhammad Iqbal Perspektif Pendidikan Islam sebagai Upaya Pengembangan dan Penguatan Karakter Generasi Milenial. JMP Online, 2(7), 711-718.

Saputra, E. (2012). Eksistensi PKN sebagai Pendidikan Nilai dalam Membangun Karakter Bangsa. Tingkap, VIII(2), 145-158.

Sawaluddin. (2018). Konsep Evaluasi dalam Pembelajaran Pendidikan Islam. Jurnal AlThariqah, 3(1), 39-53.

Shobahiya, M., \& Suseno, A. (2013). Konsep Pendidikan Karakter Berbasis Potensi Diri dalam Film the Miracle Worker. Suhuf, 25(1), 76-99.

Situmorang, M. (2013). Pengembangan Buku Ajar Kimia SMA melalui Inovasi Pembelajaran dan Integrasi Pendidikan Karakter untuk Meningkatkan Hasil Belajar Siswa. In Semirata FMIPA Universitas Lampung (pp. 237-246).

Suhady, I., \& Sinaga, A. M. (2006). Wawasan Kebangsaan dalam Kerangka NKRI. Jakarta: Lembaga Administrasi Negara RI.

Suwito. (2004). Filsafat Pendidikan Akhlak Ibn Miskawaih. Yogyakarta: Belukar.

Wahana, H. D. (2015). Pengaruh Nilai-Nilai Budaya Generasi Millennial dan Budaya Sekolah Terhadap Ketahanan Individu (Studi di SMA Negeri 39, Cijantung, Jakarta). Jurnal Ketahanan Nasional, XXI(1), 14-22.

Wahono, M. (2018). Pendidikan Karakter: Suatu Kebutuhan Bagi Mahasiswa di Era Milenial. Integralistik, XXIX(2), 1-8.

Wahyudi, A. (2004). Ideologi Pancasila: Doktrin yang Komperehensif atau Konsepsi Politis. Yogyakarta: Pusat Studi Pancasila UGM.

Wardani, S., Widodo, A. T., \& Priyani, N. E. (2009). Peningkatan Hasil Belajar Siswa 
melalui Pendekatan Keterampilan Proses Sains Berorientasi Problem-Based Instruction. Jurnal Inovasi Pendidikan Kimia, 3(1), 391-399.

Wibowo, A. M. (2014). Internalisasi Nilai-Nilai Karakter Bangsa melalui Mata Pelajaran PAI pada SMA eks RSBI di Pekalongan. Analisa, 21(2), 291-303.

Yuliana, E. D. (2012). Pentingnya Pendidikan Karakter Bangsa Merevitalisasi Ketahanan Bangsa. Jurnal Udayana Mengabdi, 9(2), 92-100.

Zuhal. (2000). Visi Iptek Memasuki Milenium III. Jakarta: UI-Press. 